Article

\title{
Incorporating Sustainability into Engineering and Chemical Education Using E-Learning
}

\author{
Edmond Sanganyado ${ }^{1,2, *(D)}$ and Simbarashe Nkomo $^{3}$ \\ 1 Marine Biology Institute, Shantou University, Shantou 515063, China \\ 2 Department of Applied Chemistry, National University of Science and Technology, \\ Ascot, Bulawayo, Zimbabwe \\ 3 Division of Natural Science and Mathematics, Oxford College of Emory University, \\ Oxford, GA 30054, USA; simbarashe.nkomo@emory.edu \\ * Correspondence: esang001@ucr.edu; Tel.: +86-150-1727-0075
}

Received: 15 February 2018; Accepted: 12 March 2018; Published: 23 March 2018

\begin{abstract}
The purpose of this study was to develop e-learning activities that could facilitate the integration of sustainability concepts and practices in engineering and chemical education. Using an online learning management system (LMS), undergraduate students in an applied chemistry program at a public university in Zimbabwe participated in an online discussion on the role of chemical reaction engineering in achieving environmental sustainability goals. In the second activity, the students were instructed to prepare a design report for a cost-effective and innovative wastewater treatment plant for a rural hospital. The design report was evaluated through peer review online. Quantitative and qualitative analyses were performed on the two online activities to evaluate student engagement, quality of responses and the incorporation of sustainability into their learning. In the online discussion, 97 comments were made averaging 120 words per comment. Furthermore, the students averaged 3.88 comments, with the majority of comments exhibiting simple and complex argumentation, a deep reflection and widespread use of terms associated with sustainability such as recycling, pollution, waste and the environment. Furthermore, the evaluation of peer reviews revealed that participants demonstrated they could identify the strengths and shortcomings in the design reports. Therefore, this study demonstrated that e-learning, particularly peer review and online discussion, could help chemistry and engineering students appreciate the need for chemical and engineering activities that encourage sustainable development.
\end{abstract}

Keywords: sustainability; Green Engineering; curriculum development; chemical education; engineering education

\section{Introduction}

The discharge of chemicals in to the environment and an excessive consumption of natural resources contributed to several global challenges such as climate change, loss of biodiversity, pollution, health risks and pollution [1-7]. In fact, the chemical industry is responsible for the discharge of $98 \%$ of $\mathrm{CO}_{2}$ into the atmosphere, consumption of $78 \%$ of energy, and production of 80,000 different chemicals per year. Thus, there is need for the chemical industry to incorporate sustainability from product development to marketing as well as the end of its life cycle. Sustainability helps to decrease natural resource depletion and chemical discharge in the environment, while increasing the product's economic and social benefits [8]. Engineers and industrial chemists are involved in the discovery, design, development, distribution, and disposal of products. Since they are the primary problem-solvers in the chemical industry, engineers and industrial chemists should have a demonstrable competency in sustainable development [6]. They play a crucial role in finding sustainable solutions of a chemical 
process at molecular, product, unit operation and plant level by analyzing its environmental, economic and societal impact. Educators play a critical role in ensuring engineers and industrial chemists acquire the essential knowledge, values and basics pertaining to sustainable development. Therefore, sustainability concepts and practices should be introduced into the engineering and chemical education curriculum to equip future chemical industry leaders.

Several engineering societies_-including the American Institute of Chemical Engineers, Australia Engineers, Engineers Canada and the Institution of Chemical Engineers-now consider sustainability concepts and practices key engineering competencies (Table 1) [9]. For example, one of the guidelines from Engineers Canada states that engineers "should seek and disseminate innovations that achieve a balance between environmental, social and economic factors while contributing to healthy surroundings in the built and natural environment" [10]. However, engineers can become more skillful in addressing environmental, economic and societal problems in a sustainable way through education. For that reason, in 2005, the United Nations (UN) established the Decade of Education for Sustainable Development aimed at (1) promoting quality education through teaching and learning sustainable development and (2) helping countries attain the millennium development goals (MDGs) through sustainability education [11]. In 2015, the UN further acknowledged the role of education in sustainability via the sustainable development goals (SDGs), SDG 4 in particular [12]. Therefore, it is expedient for higher education practitioners to impart sustainability skills, knowledge and values to future engineers and industrial chemists through the integration of sustainability in engineering education $[13,14]$.

Table 1. Engineering Competencies associated with sustainability.

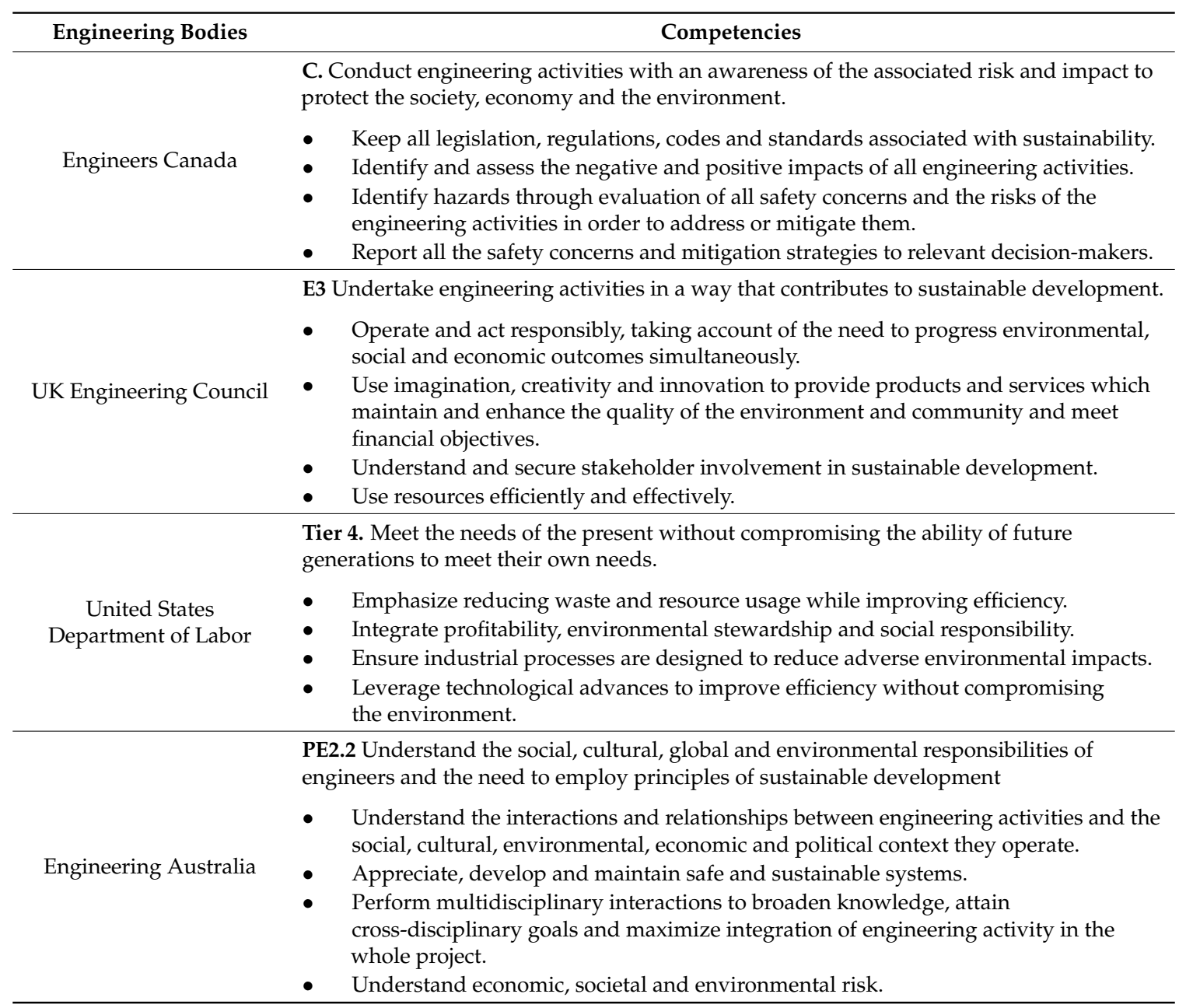




\section{Theoretical Background}

Several innovative solutions have been used to embed sustainable development in engineering and chemical education. The methods ranged from university-, teacher-, curriculum- and student-oriented approaches. In university-oriented approaches, the leadership created sustainability policies that would be integrated into all activities conducted at the university [15]. For example, the University of Johannesburg employed an innovative management strategy that involved regular planning, policy formulation, brainstorming and benchmarking sessions focused on implementing sustainability goals across the campus [16]. Although ideal, such an approach is difficult to translate to student activities in the classroom without proper teacher training and resources, hence the teacher-oriented approach. There are four approaches that have been identified concerning integrated sustainability in teacher training and these are: (1) diffusing sustainability concepts throughout the curriculum, courses and campus; (2) introduction of dedicated compulsory sustainability subjects; (3) introduction of dedicated sustainability elective subjects; and (4) including a sustainable development component in a core/compulsory subject [17]. The same approaches used in incorporating sustainability into teacher training are often used in curriculum-oriented approaches [18]. In addition, educators have incorporated sustainability into undergraduate laboratory classes by developing experiments and incorporating practices that promote sustainability such as the analysis of bioethanol [19]. using reagents extracted from plants [20]. and implementation of an environmental management system [21]. However, development of a new degree program, course (or class module) or laboratory experiments might be time consuming and costly, particularly in low- and middle- income countries. For that reason, student-oriented approaches, which focus on what the student does, offer an easier and less expensive way for embedding sustainability in engineering education.

Inquiry-based learning methods are the most widely used technique for embedding sustainability. They encourage active learning, as the student takes ownership of their learning thereby promoting the development of higher level thinking skills imperative in sustainable education [22]. A common example of inquiry-based learning employed in engineering education are final year undergraduate research projects. Individual or team research projects are help the students develop and appreciate key engineering competencies [6].Thus, research projects offer a critical bridge between the university and workplace $[6,23]$. Although integrating sustainability in engineering education is important, there is need for the educator to engage in pedagogical reflection [24]. The objectives of the pedagogical reflection should include establishing the level of understating the learner achieved and the sustainability concepts and practices the learner remembered. Student responses in online activities can be a valuable resource for pedagogical reflection. For example, sustainability encompasses environmental, social or cultural, stakeholders, politics, economic and scientific and multi-disciplinary aspects. Through analysis on the students' responses and grouping the words they used into the six categories would help establish whether the students grasped the interdisciplinary nature of sustainability [24]. An LMS such as Canvas could make it easier to engage in pedagogical reflection as the educator can make formative assessment activities available online.

The increase in internet penetration rate across Africa in the past decade has made e-learning a viable tool for integrating sustainability in higher education [25]. Although e-learning can be challenging in Africa due to student and teacher perceptions and a lack of resources, several studies have found e-learning could improve student engagement and retention as it encourages social interaction and sharing of documents [26,27]. Furthermore, e-learning can be used for harnessing intellectual capital through international collaborative learning [25]. Learning management systems (LMS) used in e-learning such as Canvas, Blackboard and Google Classroom often have features that can be used to measure student engagement. The frequency, duration and regularity with which students use the LMS features can be used to measure student engagement [27]. For example, in a study on cultural and social views on learning, researchers used Canvas, as a platform for measuring social interaction among learners in an online discussion [26]. In an organic chemistry course, peer evaluation of class presentations using Blackboard was shown to help students acquire critical skills in effective 
communication while encouraging student engagement and interest [28]. Therefore, e-learning can be a useful tool for incorporating sustainability into engineering and chemical education.

\section{Research Question}

The study aims to explore the use of e-learning in embedding sustainability concepts and practices in engineering and chemical education. Furthermore, the study aims to develop inquiry-based learning approaches using an online LMS. Hence, the research questions, in context of process engineering, are:

1. How does an online discussion on sustainable development in Zimbabwe foster student engagement?

2. To what extent does online discussion and peer evaluation promote sustainability conscious critical discourse and reflection?

\section{Methodology}

\subsection{Classroom Description}

This study was conducted in two process engineering courses over two semesters at a public university in Zimbabwe. The courses comprised of two 120-min lectures each week and three 60-min office hours each week. The enrollment for the courses consisted of final year students studying physical sciences only. The online discussion was conducted over six weeks and the design experiment over two months. Students evaluated the design report of their peers. The students had varying experiences in e-learning. However, none of the students had previously enrolled in a course that used an LMS such as Canvas. Data were collected for 26 students, representing those students who engaged in the discussion and peer evaluation.

\subsection{Instructional Strategy}

The engineering competencies aligned to sustainability require a high level of knowledge such as designing, creating and integrating [29]. Several studies found that online discussions can encourage critical thinking [30-32]. Therefore, in this study an online discussion was developed that had learning outcomes that addressed the engineering competencies aligned to sustainable development. The discussion question focused on the role of chemical reaction in promoting sustainable development in Zimbabwe. The question was relevant and connected with the students, thus encouraging them to take responsibility for their learning. The second activity required the students to design a wastewater treatment plant for a rural hospital. However, as the future engineers and industrial chemists, the students are expected to be able to evaluate the environment, economic and social impact of a project. Therefore, the students were required to evaluate the reports of their peers by giving a score and writing a corresponding comment justifying the score. Table 2 shows the online activities used in the study and their corresponding learning outcomes. The online discussion posts, design reports and the peer evaluations where submitted on Canvas.

Table 2. Activities used in the incorporation of sustainability into process engineering.

\begin{tabular}{cllll}
\hline \multicolumn{1}{c}{ Activities } & & \multicolumn{1}{c}{ Question } & \multicolumn{1}{c}{ Learning Outcomes } & Source \\
\hline Type & \multicolumn{1}{c}{$\begin{array}{l}\text { According to Milorad P. Dudukovic, "The key } \\
\text { challenge for chemical reaction engineering is the } \\
\text { development of new more efficient and profitable } \\
\text { technologies. This is to be accomplished via an } \\
\text { improved science-based scale-up methodology for } \\
\text { transfer of molecular discoveries to sustainable } \\
\text { Online } \\
\text { discussion } \\
\text { nonpolluting processes that can meet the future } \\
\text { energy, environmental, food and materials needs of } \\
\text { the world." Discuss how chemical reaction } \\
\text { engineering can be used to meet the Millennium } \\
\text { Development Goals in Zimbabwe, particularly goal 7 } \\
\text { on environmental sustainability. }\end{array}$} & & $\begin{array}{l}\text { Apply the fundamentals of } \\
\text { reaction engineering in } \\
\text { answering } \\
\text { sustainability problems. } \\
\text { Develop an understanding of } \\
\text { the MDGs and SDGs }\end{array}$ & [33] \\
\hline
\end{tabular}


Table 2. Cont.

\begin{tabular}{|c|c|c|c|}
\hline \multicolumn{2}{|r|}{ Activities } & \multirow{2}{*}{ Learning Outcomes } & \multirow{2}{*}{ Source } \\
\hline Type & Question & & \\
\hline $\begin{array}{l}\text { Design } \\
\text { report }\end{array}$ & $\begin{array}{l}\text { Your local hospital received a report from the } \\
\text { Environmental Monitoring Agency that stated that } \\
\text { the effluent from the hospital is contaminating a } \\
\text { local river. As a design engineer, you are tasked with } \\
\text { proposing and designing a wastewater treatment } \\
\text { plant for the local hospital. Write a design report for } \\
\text { a cost-effective and innovative wastewater treatment } \\
\text { plant for the hospital. Discuss how your design is } \\
\text { sustainable and helps the nation to meet the MDG } 7 .\end{array}$ & $\begin{array}{l}\text { Apply the fundamentals of } \\
\text { reaction engineering in } \\
\text { answering } \\
\text { sustainability problems. } \\
\text { Evaluate the reliability, } \\
\text { effectiveness and limitations } \\
\text { of available tools, equipment } \\
\text { or technology for solving } \\
\text { engineering problems. } \\
\text { Develop a solution that best } \\
\text { meets system requirements } \\
\text { and specifications. }\end{array}$ & Report [34] \\
\hline
\end{tabular}

MDG 7 was used in the activities as it offers a concise reference to the SDGs relevant to process engineering; namely, SDG $6,7,9,13,14$ and 15.

\subsection{Classroom Intervention}

In a previous study, it was found that students preferred open-ended, rather than debate or case-based, discussions [30]. However, the level of critical thinking was found to be lower in open-ended discussion. Therefore, to encourage critical discourse and reflection in the online discussion, the author gave examples from developed nations on the application of sustainable development to the chemical industry once a week during lectures. Students were encouraged to reflect on how the sustainability practices from developed nations could be tailored for low- and middle-income countries.

\subsection{Data Collection}

Data was collected after the deadline of the activities had lapsed. The source of the data for this study was student responses from Canvas. The observations made in this study were primarily at the individual level and the whole classroom level. Furthermore, student responses were imported to a word processing software. In the online discussion, student engagement was measured using the length and frequency of their contribution. Since the study was part of normal university activities, no additional ethical review was needed from the Institutional Review Board. To protect the privacy of the participants, data was made available for use of this study only.

\subsection{Data Analysis}

Data analysis was comprised of determining the level of student engagement in online discussion, evaluating the quality of students' responses and assessing the students' conceptual understanding of sustainability.

\subsubsection{Student Engagement}

A good learning activity should hold the attention of the learners while encouraging them to participate. Student engagement refers to the psychological investment, time and effort a student puts toward learning. Several studies found that improving student engagement often resulted in an increase in student retention, performance and motivation [35-37]. Furthermore, social interactions with peers, learning content and instructors foster student engagement [38]. Hence, determining the level of student engagement with an online activity can provide evidence on the cognitive development of the students [30]. In this study, behavioral engagement was estimated using the frequency of student participation in the online discussion. The students were instructed to post at least two comments and no upper limit was given. A preliminary estimate of the students' cognitive engagement was estimated using the length of their responses on the online discussion.

\subsubsection{Quality of Response}

It is important to estimate the quality of the students' argumentation and reflectivity when seeking to establish the effectiveness of a learning approach. However, assessing critical thinking 
is challenging since it is not a specific ability but a complex set of broad and specific intertwined factors [30]. Critical thinking in online discussions can be assed using the Practical Inquiry Model, which focuses on metacognitive processes rather than the specific learning outcomes [30,39]. In the Practical Inquiry Model, student responses are categorized as triggering, exploration, integration or resolution use different indicators [39]. In this study, a variation of the Practical Inquiry Model was used. Briefly, participant posts from the online discussion $(\mathrm{N}=97)$ were collected from Canvas and subsequently ranked for their quality in five key aspects; namely, Argumentation, Responsiveness, Elicitation, Reflection on Individual Process and Reflection on Group Process (Table 3) [26,32]. The coding was conducted independently by two analysts and the inter-coder reliability was determined.

Table 3. Ranking scheme for quality of participant contribution.

\begin{tabular}{clllll}
\hline \multirow{2}{*}{ Dimensions } & \multicolumn{1}{c}{ Key Aspects } & \multicolumn{2}{c}{ Rank } \\
\cline { 2 - 5 } Content & Argumentation & None & Unsupported & Simple & Complex \\
\hline \multirow{2}{*}{ Discursiveness } & Responsiveness & None & Acknowledge & Respond to single idea & $\begin{array}{l}\text { Respond to multiple } \\
\text { ideas }\end{array}$ \\
\cline { 2 - 5 } Reflectivity & Elicitation & None & Unclear question & Question one person & Question whole group \\
& $\begin{array}{l}\text { Reflection in the } \\
\text { question or submission }\end{array}$ & None & $\begin{array}{l}\text { Shallow: reflection on own } \\
\text { posts with no explanation }\end{array}$ & $\begin{array}{l}\text { Deep: learning process } \\
\text { shape one's idea }\end{array}$ \\
\cline { 2 - 4 } & Riscussion & None & $\begin{array}{l}\text { Shallow: reflection on group } \\
\text { posts with no explanation }\end{array}$ & $\begin{array}{l}\text { Deep: learning process was } \\
\text { shaped by group's idea }\end{array}$ \\
\hline
\end{tabular}
Adapted from Chen et al., 2018.

After submitting the design report, the students anonymously evaluated and scored other participants' reports. Each submission was peer reviewed by three participants. Students were expected to offer constructive criticism of the design report. The quality of the peer evaluation was ranked by establishing if the reviewer identified at least one positive aspect and at least one negative aspect the design report.

\section{Results}

\subsection{Student Engagement}

The online discussion was available on Canvas between 21 January 2017 and 28 February 2017. All the participants took part in the activity, generating 97 comments. The students were required to make at least 2 contributions to the discussion. The participants averaged 120 words per comment and each participant averaged 3.88 posts in the online discussion (Figure 1). Of the 26 participants, 8 were highly active, contributing at least 5 comments each. However, 10 participants were less active as they contributed fewer than 3 comments. Eight students made 3 or 4 comments. The participants shared 11 high quality references, comprising reports from universities, government agencies and international organizations and academic papers (data not shown).

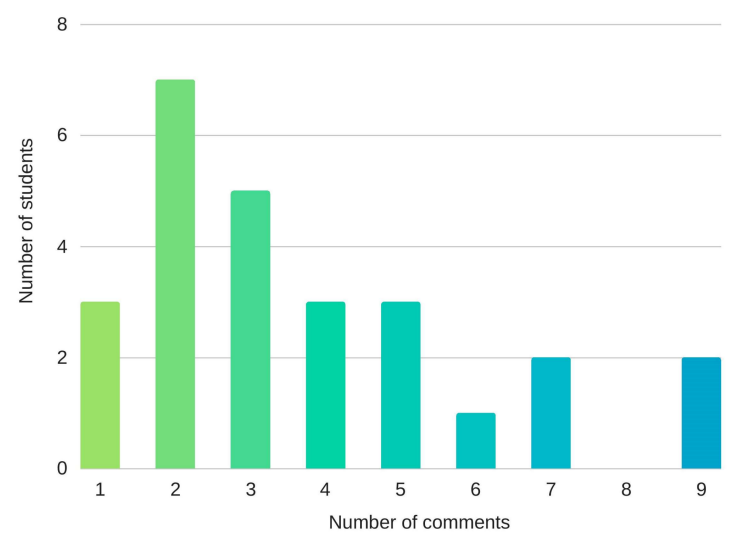

Figure 1. The level of participant engagement in an online discussion. 


\subsection{Quality of Response}

\subsubsection{Online Discussion}

The differences between the means obtained by the independent coders ranged from 0 to $7.4 \%$. This suggests the coding scheme had a high repeatability. The quality of the responses and of the argumentation and responsiveness in the comments were slightly above moderate at 2.25 and 2.16, respectively (Table 4). However, the level of elicitation was low at 0.39 . They were only 15 questions out of the 97 comments. The reflection in the post and group ideas was slightly above average at 1.24 and 1.14 , respectively.

Table 4. The total count and means of weighted conceptual engagement in online discussion.

\begin{tabular}{lccccc}
\hline \multirow{2}{*}{ Key Aspects } & \multicolumn{4}{c}{ Weight } & \multirow{2}{*}{ Mean } \\
\cline { 2 - 5 } & $\mathbf{0}$ & $\mathbf{1}$ & $\mathbf{2}$ & $\mathbf{3}$ & \\
\hline Argumentation & 6 & 8 & 39 & 44 & 2.25 \\
Responsiveness & 6 & 16 & 31 & 44 & 2.16 \\
Elicitation & 79 & 4 & 8 & 6 & 0.39 \\
Reflection in the question or submission & 16 & 42 & 39 & & 1.24 \\
Reflection on group discussion & 21 & 41 & 35 & & 1.14 \\
\hline
\end{tabular}

\subsubsection{Design Report}

Out of 26 participants, 22 submitted their design report and were double-blind reviewed by three peers. About $51.5 \%$ of the comments were poor, with participants failing to identify the positive or negative aspects of the paper they reviewed. However, $24.2 \%$ peer reviews identified at least one positive attribute of a submission. Furthermore, another $24.2 \%$ peer reviews identified at least one error in the submission reviewed. The participants identified the errors using expressions such as "lacked," "did not," "neglected," "more research" and "did not include."

\subsection{Collaborative Learning}

To determine if the participants incorporated sustainability concepts and practices into the online discussion, a word cloud was generated from the forum posts (Figure 2). All the posts from the online discussion were imported to Microsoft Word with a ProWriterAid add-on (Oxford, UK). Redundant words such as the author's last name and the last name of the author of the reading assignment were excluded from the word cloud. The whole class focused primarily on the environmental, economic and scientific aspects of sustainability as words such as environment, waste and chemical were more commonly used. However, the commonly used words did not directly relate to politics, culture and stakeholders.

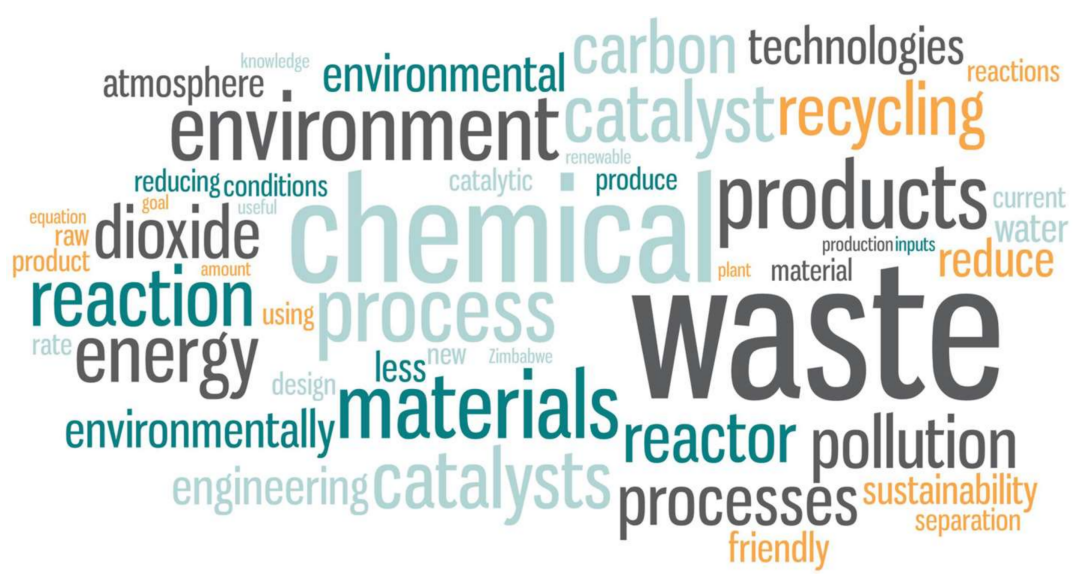

Figure 2. Visualization of the most frequent words used in the online discussion. 
To better understand how the students learned about sustainability using collaborative learning, the questions posed by the participants in the online discussion were analyzed. The participants contributed 15 questions that demonstrated the participants reflected on sustainability. Examples of the engaging questions posted on the forum are shown in Table 5.

Table 5. Elicitations in online discussions.

\begin{tabular}{ll}
\hline \multicolumn{1}{c}{ Examples of Engaging Questions * } \\
\hline 1. How does your final year project incorporate the Millennial Development Goal 7? \\
\hline 2. Are there any solvents currently used in Zimbabwe that are persistent in the environment? \\
\hline 3. $\quad \begin{array}{l}\text { How exactly does chemical reaction engineering play a role in sustaining a modern } \\
\text { Zimbabwean lifestyle? }\end{array}$ \\
\hline 4. How does chemical reaction engineering affect the environment? \\
\hline 5. $\quad \begin{array}{l}\text { Are you implying that most industrial operations in Zimbabwe are using the wrong catalysts? if so, do } \\
\text { you have examples to justify that? }\end{array}$ \\
\hline $\begin{array}{l}\text { Considering the research paper was published in 2009, is it possible that basing claims on this text may } \\
\text { fail to accommodate some recent developments in reaction engineering? }\end{array}$ \\
\hline
\end{tabular}

${ }^{*}$ Questions have been edited for clarity.

\section{Discussion and Conclusions}

The study sought to establish e-learning could be used as a tool for incorporating sustainability into engineering and chemical education in developing nations. The results suggested that e-learning activities such as online discussion and peer evaluation of design assignments promoted student engagement. Through analysis of the student comments, it was found that the students were environmental conscious and incorporated principles and practices of sustainability when formulating their arguments or assessing their peers. Such outcomes addressed the key sustainability competencies set by engineering societies such as Engineering Australia, Engineers Canada and Engineering Council.

A high student participation in the open-ended online discussion was observed as the students contributed an average of 3.88 posts per students and 120 words per post. The observed online behavioral patterns suggests the students invested significant time and effort in the activity. Furthermore, $60 \%$ of the participants made at least three comments when the required number of posts was two. The Canvas platform fostered social interaction as it possessed social media tools such as responding to other student's comments [26,40]. Furthermore, as students read each other's comments, they were motivated to high-level knowledge processing. However, although the contribution of the whole class was high, $40 \%$ of the students were passive submitting the minimum required number of posts or less. Low student participation is often ascribed to the student's digital citizenship. Students who have a low digital proficiency tend to contribute less often. Furthermore, in developing nations lack of internet access or poor connectivity can reduce student participation in online activities. However, in this study the students had free internet access on campus. The author monitored the online discussion without making any contribution. By taking up the role of a facilitator, the instructor can improve student engagement through asking additional questions, clarifying the original questions and addressing any concerns that might arise [31].

The student activities in this study were relevant, authentic and connected with the students as they focused on the societal, economic and environmental challenges in Zimbabwe. Hence, the students were probably motivated to take responsibility of their learning as indicated by the quality of their argumentation and the depth of their reflections. The students demonstrated critical thinking skills because $75 \%$ of their comments in the online discussion were built on at least one idea. However, about 
$40 \%$ of the comments showed deep reflection with the students explaining how they were learning sustainable development. However, it was previously observed that when a student considered the online activity to be highly important they became cognitively and emotionally engaged to the task [37]. Cognitive and emotional engagement can be enhanced when the instructor acts as the facilitator who regularly demonstrate the importance of the activity.

The participants managed to incorporate sustainability concepts and practices in their arguments. The word cloud (Figure 2), demonstrated the students included sustainability aspects when formulating their arguments. For example, the following words were widely used; reaction, process, raw materials, inputs, conditions, pollution, which are associated with engineering competencies of foundations of engineering, design, manufacturing and construction, engineering economics, operations and maintenance and safety, respectively [29]. However, the arguments made by the students overlooked political and cultural aspects of sustainable development.

Thus, online learning offered a platform for students to actively learn about sustainability. This study provides instructors with techniques on how to incorporate sustainability into chemical and engineering education. Furthermore, in this study we used and demonstrated techniques for assessing the quality of student responses.

Author Contributions: E.S. conceived, designed and performed the experiments; E.S. and S.N. organized and analyzed the data; E.S. wrote the paper with editorial support from S.N.

Conflicts of Interest: The authors declare no conflict of interest.

\section{References}

1. Sanganyado, E.; Lu, Z.; Fu, Q.; Schlenk, D.; Gan, J. Chiral pharmaceuticals: A review on their environmental occurrence and fate processes. Water Res. 2017, 124, 527-542. [CrossRef] [PubMed]

2. Sanganyado, E.; Rajput, I.R.; Liu, W. Bioaccumulation of organic pollutants in Indo-Pacific humpback dolphin: A review on current knowledge and future prospects. Environ. Pollut. 2018, 237, 111-125. [CrossRef] [PubMed]

3. Sanganyado, E.; Teta, C.; Masiri, B. Impact of African traditional worldviews on climate change adaptation. Integr. Environ. Assess. Manag. 2018, 14, 189-193. [CrossRef] [PubMed]

4. Gwenzi, W.; Chaukura, N. Organic contaminants in African aquatic systems: Current knowledge, health risks and future research directions. Sci. Total Environ. 2018, 619-620, 1493-1514. [CrossRef]

5. Bondarczuk, K.; Markowicz, A.; Piotrowska-Seget, Z. The urgent need for risk assessment on the antibiotic resistance spread via sewage sludge land application. Environ. Int. 2016, 87, 49-55. [CrossRef] [PubMed]

6. Belu, R.; Chiou, R.; Tseng, T.-L. (Bill); Cioca, L. Advancing sustainable engineering practice through education and undergraduate research projects. In Education and Globalization; ASME: Montreal, QC, Canada, 2014; Volume 5, pp. 1-8.

7. Teta, C.; Hikwa, T. Heavy Metal Contamination of Ground Water from an Unlined Landfill in Bulawayo, Zimbabwe. J. Heal. Pollut. 2017, 7, 18-27. [CrossRef]

8. Allen, D.T.; Shonnard, D.R.; Huang, Y.; Schuster, D. Green Engineering Education in Chemical Engineering Curricula: A Quarter Century of Progress and Prospects for Future Transformations. ACS Sustain. Chem. Eng. 2016, 4, 5850-5854. [CrossRef]

9. Sheehan, M.; Schneider, P.; Desha, C. Implementing a systematic process for rapidly embedding sustainability within chemical engineering education: a case study of James Cook University, Australia. Chem. Educ. Res. Pract. 2012, 13, 112-119. [CrossRef]

10. Engineers Canada. National Guideline on Sustainable Development and Environmental Stewardship for Professional Engineers; Engineers Canada: Ottawa, ON, Canada, 2016.

11. UNESCO. United Nations Decade of Education for Sustainable Development (2005-2014): International Implementation Scheme; UNESCO: Paris, France, 2005.

12. Annan-Diab, F.; Molinari, C. Interdisciplinarity: Practical approach to advancing education for sustainability and for the Sustainable Development Goals. Int. J. Manag. Educ. 2017, 15, 73-83. [CrossRef]

13. Wright, T.S.A. Definitions and frameworks for environmental sustainability in higher education. High. Educ. Policy 2002, 15, 105-120. [CrossRef] 
14. Hawkins, N.C.; Patterson, R.W.; Mogge, J.; Yosie, T.F. Building a sustainability road map for engineering education. ACS Sustain. Chem. Eng. 2014, 2, 340-343. [CrossRef]

15. Louw, W. Green curriculum: Sustainable learning at a higher education institution. Int. Rev. Res. Open Distance Learn. 2013, 14. [CrossRef]

16. Barnard, Z.; Van der Merwe, D. Innovative management for organizational sustainability in higher education. Int. J. Sustain. High. Educ. 2016, 17, 208-227. [CrossRef]

17. Evans, N. (Snowy); Stevenson, R.B.; Lasen, M.; Ferreira, J.-A.; Davis, J. Approaches to embedding sustainability in teacher education: A synthesis of the literature. Teach. Teach. Educ. 2017, 63, 405-417. [CrossRef]

18. Verbitskaya, L.A.; Nosova, N.B.; Rodina, L.L. Sustainable development in higher education in Russia: The case of St. Petersburg State University. High. Educ. Policy 2002, 15, 177-185. [CrossRef]

19. Galgano, P.D.; Loffredo, C.; Sato, B.M.; Reichardt, C.; El Seoud, O.A. Introducing education for sustainable development in the undergraduate laboratory: Quantitative analysis of bioethanol fuel and its blends with gasoline by using solvatochromic dyes. Chem. Educ. Res. Pract. 2012, 13, 147-153. [CrossRef]

20. Kradtap Hartwell, S. Exploring the potential for using inexpensive natural reagents extracted from plants to teach chemical analysis. Chem. Educ. Res. Pract. 2012, 13, 135-146. [CrossRef]

21. Montañés, M.T.; Palomares, A.E.; Sánchez-Tovar, R. Integrating sustainable development in chemical engineering education: The application of an environmental management system. Chem. Educ. Res. Pract. 2012, 13, 128-134. [CrossRef]

22. Pretorius, R.; Lombard, A.; Khotoo, A. Adding value to education for sustainability in Africa with inquiry-based approaches in open and distance learning. Int. J. Sustain. High. Educ. 2016, 17, 167-187. [CrossRef]

23. Fenner, R.A.; Ainger, C.M.; Cruickshank, H.J.; Guthrie, P.M. Embedding sustainable development at Cambridge University Engineering Department. Int. J. Sustain. High. Educ. 2005, 6, 229-241. [CrossRef]

24. Lourdel, N.; Gondran, N.; Laforest, V.; Brodhag, C. Introduction of sustainable development in engineers' curricula. Int. J. Sustain. High. Educ. 2005, 6, 254-264. [CrossRef]

25. Protsiv, M.; Rosales-Klintz, S.; Bwanga, F.; Zwarenstein, M.; Atkins, S. Blended learning across universities in a South-North-South collaboration: A case study. Heal. Res. Policy Syst. 2016, 14, 67. [CrossRef] [PubMed]

26. Chen, B.; Chang, Y.-H.; Ouyang, F.; Zhou, W. Fostering student engagement in online discussion through social learning analytics. Internet High. Educ. 2018, 37, 21-30. [CrossRef]

27. Mathews, A.L.; LaTronica-Herb, A. Using Blackboard to Increase Student Learning and Assessment Outcomes in a Congressional Simulation. J. Polit. Sci. Educ. 2013, 9, 168-183. [CrossRef]

28. Kadnikova, E.N. "Molecules-in-Medicine": Peer-evaluated presentations in a fast-paced organic chemistry course for medical students. J. Chem. Educ. 2013, 90, 883-888. [CrossRef]

29. United States Department of Labor. Engineering Competency Model; United States Department of Labor: Washington, DC, USA, 2015.

30. Richardson, J.C.; Ice, P. Investigating students' level of critical thinking across instructional strategies in online discussions. Internet High. Educ. 2010, 13, 52-59. [CrossRef]

31. Ouyang, F.; Scharber, C. The influences of an experienced instructor's discussion design and facilitation on an online learning community development: A social network analysis study. Internet High. Educ. 2017, 35, 34-47. [CrossRef]

32. Wise, A.; Zhao, Y.; Hausknecht, S. Learning Analytics for Online Discussions: Embedded and Extracted Approaches. J. Learn. Anal. 2014, 1, 48-71. [CrossRef]

33. Dudukovic, M.P. Reaction engineering: Status and future challenges. Chem. Eng. Sci. 2010, 65, 3-11. [CrossRef]

34. United Nations Economic and Social Council. Progress towards the Sustainable Development Goals: Report of the Secretary-General; United Nations Economic and Social Council: New York, NY, USA, 2016.

35. Kahu, E.R. Framing student engagement in higher education. Stud. High. Educ. 2013, 38, 758-773. [CrossRef]

36. Coates, H. The value of student engagement for higher education quality assurance. Qual. High. Educ. 2005, 11, 25-36. [CrossRef]

37. Manwaring, K.C.; Larsen, R.; Graham, C.R.; Henrie, C.R.; Halverson, L.R. Investigating student engagement in blended learning settings using experience sampling and structural equation modeling. Internet High. Educ. 2017, 35, 21-33. [CrossRef] 
38. Czerkawski, B.C.; Lyman, E.W. An instructional design framework for fostering student engagement in online learning environments. TechTrends 2016, 60, 532-539. [CrossRef]

39. Garrison, D.R.; Anderson, T.; Archer, W. Critical inquiry in a text-based environment: computer conferencing in higher education. Internet High. Educ. 1999, 2, 87-105. [CrossRef]

40. Joksimović, S.; Dowell, N.; Poquet, O.; Kovanović, V.; Gašević, D.; Dawson, S.; Graesser, A.C. Exploring development of social capital in a CMOOC through language and discourse. Internet High. Educ. 2018, 36, 54-64. [CrossRef]

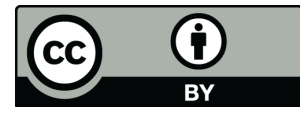

(c) 2018 by the authors. Licensee MDPI, Basel, Switzerland. This article is an open access article distributed under the terms and conditions of the Creative Commons Attribution (CC BY) license (http://creativecommons.org/licenses/by/4.0/). 